\section{Evaluation of chloride resistance of silica fume and glass waste MWCNT- geopolymer composite}

H. M. KHATER

Professor of cement chemistry at Raw Building Materials Technology and Processing Research Institute, Housing and Building National Research Center (HBRC). Supervisor of XRF laboratory for the chemical analysis of all type of raw building materials.

H. M. KHATER - Housing and Building National Research Centre (HBNRC), Cairo - Hkhater4@yahoo.com

AbDeEn EL NAGAR - Housing and Building National Research Centre (HBNRC), Cairo

Érkezett: 2020. 08. 30. - Received: 30. 08. 2021. - https://doi.org/10.14382/epitoanyag-jsbcm.2021.8
Researcher in the field of geology at Raw Building Materials Technology and Processing Research Institute, Housing and Building National Research Center (HBRC)

\title{
Abstract
}

The target of the present paper is to study the enhancement effect of MWCNT on alkali activated composites resistivity to chloride attack. Geopolymer composites were made from metakaolin and ground granulated blast furnace slag and to either $10 \%$ silica fume or glass waste. The added MWCNT were in the ratio of $0.01 \%$ up to $0.09 \%$ by weight. Results revealed the high resistivity and stability against magnesium chloride solution; in addition glass waste mixes acquired high mechanical strength as compared with silica fume mixes as related to the high amorphous structure as well as high finesty of glass waste as compared with silica fume. The results revealed an increased enhancement in characteristics of activated composites with MWCNT up to $0.07 \%$ in both matrices.

Keywords: MWCNT, alkali activation, glass waste, silica fume

Kulcsszavak: MWCNT, alkáli aktiválás, üveghulladék, szilikapor

\section{Introduction}

Interest in the development of alternative building materials such as alkali-activated binders has been promoted by growing development in building industry and the need for materials with high superior properties with high sustainable properties. Alkali-activated binders represent an attractive alternative for the partial or almost complete substitution of cement in construction industry as they offer durable, high performance in addition to low production cost [1], low greenhouse gas emissions [2,3]. There is a general agreement that alkaliactivated cements can offer cradle-to-gate greenhouse emission savings approaching $40-80 \%$ compared to Portland cement for a performance-equivalent material.

Alkali activated composites are inorganic polymer binder that processed at room temperature upon activation of alumino-silicate sources using alkali metal oxides. Metakaolinbased geopolymer is one of the most abundant and applicable alumino-silicate polymers worldwide [4]. The synthesis of geopolymer proceeds via polycondensation reactions of metakaolinite (kaolinite calcined at $600-800^{\circ} \mathrm{C}$ ) or other natural and industrial aluminosilicate reach materials as water cooled slag, silica fume fly ash with alkaline solution [5]. In spite metakaolin-based geopolymers possess interesting properties; they have not enough high strength and show brittle behavior. These make the products unsuitable for structural and infrastructural applications; thus, it is necessary to improve the fracture properties of metakaolin-based geopolymers [6]. Many previous studies investigated their reinforcing with various macrofiber as steel, polypropylene (PP), poly vinyl chloride (PVC), and basalt fibers $[7,8]$. The addition of these fibers increased the flexural strength, fracture energy, and controlled the crack propagation. Multiwall carbon nanotubes (MWCNTs) are being considered as a potential reinforcement in composites because they have mechanical properties superior

to those of traditional fibers and possess a Young's modulus of $1 \mathrm{TPa}$, a yield stress of 100-300 GPa, and a tensile strength of $63 \mathrm{GPa}$ [9]. However, the higher mechanical properties of MWCNTs alone do not ensure a mechanically superior nanocomposites geopolymer. It is clear that the dispersion of the MWCNTs within the metakaolin-based geopolymers and the bonding properties between the surface of the MWCNTs and the metakaolin-based geopolymers around them are the main challenges in the fabrication of metakaolin/MWCNTs composites [10,11].

Maeva et al., [12] showed that using nanodispersed carbon additives as a modifier in anhydrite compositions provided a dense, low-defect structure of crystalline hydrates, leading to the increased mechanical strength and water resistance of the material. However, the effective application of multiwalled carbon nanotube dispersions required the solution of the problem connected with partial separation of carbon nanotubes into individual particles in the aqueous dispersion medium as well as the problem of stabilizing nanostructures in dispersion while being stored. The solution of the problem of stabilizing suspensions is adsorbing and solvent layer on the surface of nanotubes which prevents their approximation. The best variant to limit coagulation is to use surfactants [13].

Previous studies have shown that sodium hydroxide $(\mathrm{NaOH})$ acts as a surfactant and removes oxidation debris from the surface of the MWCNTs, consequently allowing them to debundle and form well-dispersed nanotubes within geopolymer matrix [11]. Recently, Khater and Abdel Gawwad [14, 15] investigated the effect of various ratios of MWCNTs dispersed with carboxylate based superplasticizer on the properties of slag geopolymeric mortar and found that the enhancement in mechanical strength with MWCNT as the high stability against firing up to $500{ }^{\circ} \mathrm{C}$. Also Farag et al., [16] studied the 


\begin{tabular}{|c|c|c|c|c|c|c|c|c|c|c|c|c|c|c|c|c|}
\hline Oxide content $/ \%$ & $\mathrm{SiO}_{2}$ & $\mathrm{Al}_{2} \mathrm{O}_{3}$ & $\mathrm{Fe}_{2} \mathrm{O}_{3}$ & $\mathrm{CaO}$ & Mgo & $\mathrm{SO}_{3}$ & $\mathrm{~K}_{2} \mathrm{O}$ & $\mathrm{Na}_{2} \mathrm{O}$ & $\mathrm{TiO}_{2}$ & Mno & $\mathbf{P}_{2} \mathbf{O}_{5}$ & Cl- & L.0.I & $\mathrm{BaO}$ & Sro & Total \\
\hline $\begin{array}{l}\text { Water - Cooled Slag } \\
\text { (GGBFS) }\end{array}$ & 36.67 & 10.31 & 0.50 & 38.82 & 1.70 & 2.17 & 1.03 & 0.48 & 0.57 & 4.04 & 0.04 & 0.050 & 0.12 & 3.28 & 0.18 & 99.96 \\
\hline Kaolin & 56.38 & 27.61 & 1.32 & 0.18 & 0.06 & 0.06 & 0.04 & 0.08 & 3.73 & - & 0.13 & 0.05 & 10.17 & - & - & 99.76 \\
\hline $\begin{array}{l}\text { MK (fired kaolin at } 800 \\
\text { degree for } 2 \mathrm{hrs} \text { ) }\end{array}$ & 57.50 & 35.10 & 1.59 & 0.64 & 0.17 & 0.25 & 0.15 & 0.12 & 2.85 & 0.00 & 0.13 & 0.06 & 1.14 & - & - & 99.70 \\
\hline Silica fume & 94.92 & 0.02 & 1.28 & 0.03 & 0.01 & 0.02 & 0.15 & 0.28 & - & - & - & - & 3.28 & - & - & 99.99 \\
\hline Glass waste & 72.00 & 1.19 & 0.39 & 9.17 & 3.98 & 0.44 & 0.23 & 11.10 & 0.08 & 0.05 & - & - & 1.09 & - & 0.01 & 99.73 \\
\hline
\end{tabular}

Table 1 Chemical composition of starting materials

1. táblázat A kiindulási anyagok kémiai összetétele

enhancement of water cooled slag geopolymer by multiwall carbon nanotube and studied their effects on their mechanical and microstructure characteristics.

Morsy et al. [17] have investigated also the effect of different concentrations of MWCNTs with nanoclay particles on the compressive strength of cement mortar and they noticed that the nanoclay particles improved the dispersion of CNTs within the mortar. Lio et al. [18] studied also the influence of MWCNTs mixed with silica fume (SF) on the mechanical property of cement-based composites. Hunashyal et al. [19] on the other hand fabricated hybrid composites of plain cement by integrating both carbon micro-fibers (CMFs) and MWCNTs.

As known that the immersion in chloride solution resulted in rapid deterioration and softening to the concrete structure, this can be related to the corrosive action depends on the concentration of chloride solution and the kind of cation linked to the chloride ion as reported by Barnes and Bensted[20]. The chloride ions penetration is dependent not only on the porosity of the matrix, but also on the paste composition and the ion-exchange capacity of the system. The damage influence of chloride is either chemical by interaction with liberated lime from the hydration reaction forming what is known as Friedel's salt or hydrocalumite $\left(\mathrm{C}_{3} \mathrm{~A} \cdot \mathrm{CaCl}_{2} \cdot 10 \mathrm{H}_{2} \mathrm{O}\right)$ causing softening to the composition.

Jun et al. [21] investigated the chloride-binding capacity of alkali-activated fly ash and slag samples and their synthesized Clbearing phases, which are capable of binding and immobilizing chloride when seawater is used as the mixing water.

In the current work, we aim to examine the stability of the alkali activated composites enhanced with MWCNT against immersion in magnesium chloride solution up to 6 months and trace the formed structures using XRD, FTIR, and DTG as well as study the mechanical stability up on immersion in the solution.

\section{Experimental}

\subsection{Materials}

The materials, which used in this investigation, are ground granulated blast furnace slag (GGBFS), sourced from Iron and Steel Factory - Helwan, Egypt. Kaolinite collected from ElDehesa, South Sinai, Egypt, which was thermally treated at 800 ${ }^{\circ} \mathrm{C}$ for $2 \mathrm{hrs}$ with a heating rate of $5^{\circ} \mathrm{C} / \mathrm{min}$ to produce metakaolin (Mk) $[22,23]$. Silica fume sourced from Suez Cement Company (Helwan plant) also known as micro-silica is a by-product of the reduction of high-purity quartz with coal in electric furnaces in the production of silicon and ferrosilicon alloys; it was in the powder form with $95 \% \mathrm{SiO}_{2}$, where about $90 \%$ of particles are of $200 \mu \mathrm{m}$ diameter, while glass waste powder prepared by grinding glass up to fine structure with an average particle size of $38 \mu \mathrm{m}$ as measured by laser particle size distribution.

Chemical compositions of the starting raw materials are given in Table 1. The activators used in the activation process are potassium hydroxide $(\mathrm{KOH})$ bought from Fisher scientific company with $99 \%$ purity in the ratio of $10 \%$ from the total weight. Whereas liquid sodium silicate (LSS, $\mathrm{Na}_{2} \mathrm{SiO}_{3} \cdot 9 \mathrm{H}_{2} \mathrm{O}$ ) from Fisher company consists of $32 \% \mathrm{SiO}_{2}$ and $17 \% \mathrm{Na}_{2} \mathrm{O}$ with silica modulus $\mathrm{SiO}_{2} / \mathrm{Na}_{2} \mathrm{O}$ equal 1.88 and its density is $1.46 \mathrm{~g} / \mathrm{cm}^{3}$ used as another source of alkali activators in the ratio of $5 \%$. Magnesium chloride with purity of $99 \%$ used as aggressive solution and was brought from Aldrich Company.

Mineralogical compositions of starting raw materials are represented in Fig. 1; where ground granulated blast furnace slag known also as water cooled slag composed of amorphous materials and kaolinite material mostly diminished upon thermal treatment at $800{ }^{\circ} \mathrm{C}$ for $2 \mathrm{hrs}$ forming amorphous metakaolin. Silica fume and glass waste are nearly composed of amorphous materials, whereas the glass waste structure acquire more amorphous constituents than silica fume.

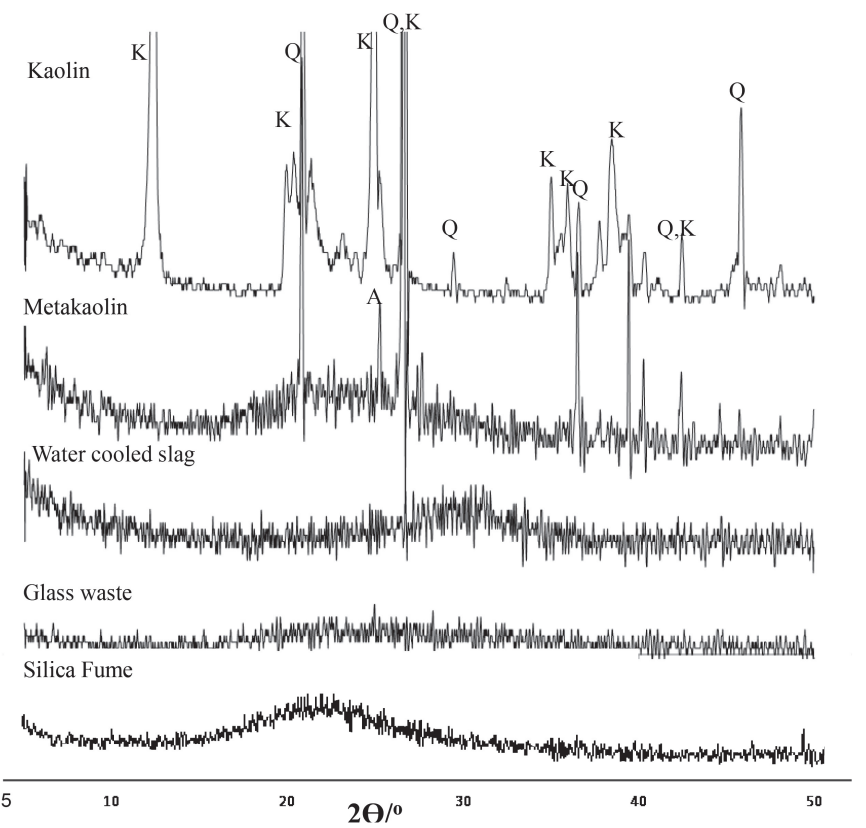

Fig. 1 X-Ray diffraction pattern of the starting raw materials (K: Kaolin, Q:Quartz:, A: Anatase)

1. ábra A kiindulás anyagok röntgendiffrakciós mintája (K: Kaolin, Q: kvarc, A Anatáz) 
Multi-walled carbon nanotubes used in this study were synthesized using a $\mathrm{Co} / \mathrm{MgO}$ based catalyst using $\mathrm{CVD}$ instrument (housing and building national research center, Egypt), the physical properties of the MWCNTs used in the study are given in Table 2.

\begin{tabular}{ccccccc}
$\begin{array}{c}\text { Amor- } \\
\text { phous } \\
\text { carbon } \\
{[\%]}\end{array}$ & $\begin{array}{c}\text { Surface } \\
{\left[\mathrm{m}^{2} \cdot \mathrm{g}^{-1}\right]}\end{array}$ & $\begin{array}{c}\text { Purity } \\
{[\%]}\end{array}$ & Ash [\%] & $\begin{array}{c}\text { Length } \\
{[\mu \mathrm{m}]}\end{array}$ & $\begin{array}{c}\text { Inner } \\
\text { dia- } \\
\text { meter } \\
{[\mathrm{nm}]}\end{array}$ & $\begin{array}{c}\text { Aspect } \\
\text { ratio } \\
{[\%]}\end{array}$ \\
\hline 0 & $>300$ & 97 & 3 & $1-5$ & $20-30$ & 120
\end{tabular}

Table 2 Properties of CNTs synthesized by using CVD apparatus

2. táblázat A karbon-nanocsövek tulajdonságai CVD készülékkel meghatározva

\subsection{Dispersion of MWCNTs}

MWCNTs were first mixed with Gelenium Ace 30-polycarboxylate-based superplasticizer and 50\% of the added water. This Polycarboxylate-based superplasticizer has been proven to be effective for CNTs dispersion [24,25]. The solution was sonicated using a Fritish 450 Sonifier Analog Cell distributor for $15 \mathrm{~min}$ [26]. Solutions with concentration of $0.01,0.03,0.05,0.07$ and 0.09 wt $\%$ of the total weight of the matrix were used to identify the MWCNT optimum concentrations and their resistivity to aggressive medium.

\subsection{Alkali activation, curing and casting}

Activation and curing are processed according to the following steps:

1. First activators prepared 24 hrs prior to casting, whereas binder reinforced with MWCNT concentrations: 0.0 (control), 0.01 up to 0.09 wt.\% of the total weight.

2. MWCNT particles sonicated for 15 min using half of the used water as well as used superplasticizer for better dispersion under a temperature of $40{ }^{\circ} \mathrm{C}$.

3. The geopolymer binder passing a sieve of $90 \mu \mathrm{m}$ as represented in Table 3 were hand mixed with the alkaline activator solution dissolved in the remaining used water for $10 \mathrm{~min}$ followed by a further $5 \mathrm{~min}$ using rotary mixer and mixed at medium speed $(80 \mathrm{rpm})$ for another 30 seconds.

4. MWCNT and superplasticizer were then added and stirred with the mixture at high speed for additional 30 seconds.

5. Paste mixtures were cast into cubic-shaped moulds with $2.5 \mathrm{~cm}$ length, vibrated for compaction, sealed with a lid to minimize any loss of evaporable water, left to cure undisturbed under ambient temperature for $24 \mathrm{hrs,}$ demolded and then subjected to curing at $40{ }^{\circ} \mathrm{C}$ with $100 \%$ relative humidity (R.H.) for 28 days [27].

6. All mixes were then immersed in $5 \% \mathrm{MgCl}_{2}$ solution [28], whereas the solution was replaced monthly, while their strength values were recorded, finally the crushed cubes were stopped for further hydration using acetone/methyl alcohol method (1:1) [29, 30], finally tightly conserved in container until examination time.

\subsection{Exploration techniques}

Chemical analysis was carried out using Axios (PW4400) WD-XRF Sequential Spectrometer (Panalytical, Netherland). Compressive strength tests were carried out using five tones German Brüf pressing machine with a loading rate of $100 \mathrm{~kg} /$ min determined according to [31]. X-ray diffraction (XRD) analysis was recorded on a Philips PW 1050/70 Diffractometer using a $\mathrm{Cu}-\mathrm{Ka}$ source with a post sample $\mathrm{Ka}$ filter. XRD patterns were obtained from $0^{\circ}$ to $50^{\circ} 2 \theta$ (step size $0.02^{\circ} 2 \theta$ and speed $0.4 \% \mathrm{~min}$ ). Quartz silica was used as an internal standard. Data were identified according to the XRD software (pdf-2: database on CD-Release 2005). Bonding characteristics of the alkali activated specimens were analyzed using a Jasco-6100 Fourier transform infrared spectrometer FTIR. Test sample was ground and uniformly mixed with $\mathrm{KBr}$ at a weight ratio $\mathrm{KBr}$ : specimen=200:1. The mixture, $0.2 \mathrm{~g}$ was pressed to a disk of $13 \mathrm{~mm}$ in diameter for analysis at $8 \mathrm{t} / \mathrm{cm}^{2}$. The wave number

\begin{tabular}{|c|c|c|c|c|c|c|c|c|c|c|c|c|c|}
\hline $\begin{array}{l}\text { Mix } \\
\text { no. }\end{array}$ & $\begin{array}{c}\text { Water } \\
\text { cooled } \\
\text { slag } \\
\text { (WCS)/\% }\end{array}$ & $\begin{array}{l}\text { Meta- } \\
\text { kaoline } \\
\text { (Mk)/\% }\end{array}$ & $\begin{array}{l}\text { Silica } \\
\text { fume } \\
(S F) / \%\end{array}$ & $\begin{array}{l}\text { Waste } \\
\text { glass } \\
\text { (WG)/\% }\end{array}$ & MWCNT/\% & КОН/\% & $\underset{2}{\mathrm{Na}} \mathrm{SiO} / \%$ & $\begin{array}{c}\text { Super- } \\
\text { plasticizer } \\
\text { (SP)/\% }\end{array}$ & $\begin{array}{c}\text { Water/ } \\
\text { binder\% }\end{array}$ & $\begin{array}{l}\mathrm{SiO}_{2} \mathrm{~J} \\
\mathrm{Al}_{2} \mathrm{O}_{3}\end{array}$ & $\begin{array}{l}\text { Total } \\
\mathrm{M}_{2} \mathrm{O} / \\
\mathrm{Al}_{2} \mathrm{O}_{3}\end{array}$ & $\begin{array}{l}\text { Total } \\
\mathrm{M}_{2} \mathrm{O} / \\
\mathrm{SiO}_{2}\end{array}$ & $\begin{array}{l}\text { Total } \\
W_{4} / \\
M_{2} O\end{array}$ \\
\hline so & 50 & 40 & 10 & - & 0.00 & 10 & 5 & 0.80 & 0.16 & 2.73 & 0.712 & 0.153 & 6.64 \\
\hline S1 & 50 & 40 & 10 & - & 0.01 & 10 & 5 & 0.80 & 0.16 & 4.64 & 0.712 & 0.153 & 6.64 \\
\hline S2 & 50 & 40 & 10 & - & 0.03 & 10 & 5 & 1.00 & 0.16 & 4.64 & 0.712 & 0.153 & 6.64 \\
\hline S3 & 50 & 40 & 10 & - & 0.05 & 10 & 5 & 1.20 & 0.16 & 4.64 & 0.712 & 0.153 & 6.64 \\
\hline S4 & 50 & 40 & 10 & - & 0.07 & 10 & 5 & 1.40 & 0.16 & 4.64 & 0.712 & 0.153 & 6.64 \\
\hline S5 & 50 & 40 & 10 & - & 0.09 & 10 & 5 & 1.60 & 0.16 & 4.64 & 0.712 & 0.153 & 6.64 \\
\hline GO & 50 & 40 & - & 10 & 0.00 & 10 & 5 & 0.80 & 0.26 & 2.60 & 0.800 & 0.18 & 9.54 \\
\hline G1 & 50 & 40 & - & 10 & 0.01 & 10 & 5 & 0.80 & 0.26 & 4.41 & 0.800 & 0.18 & 9.54 \\
\hline G2 & 50 & 40 & - & 10 & 0.03 & 10 & 5 & 1.00 & 0.26 & 4.41 & 0.800 & 0.18 & 9.54 \\
\hline G3 & 50 & 40 & - & 10 & 0.05 & 10 & 5 & 1.20 & 0.26 & 4.41 & 0.800 & 0.18 & 9.54 \\
\hline G4 & 50 & 40 & - & 10 & 0.07 & 10 & 5 & 1.40 & 0.26 & 4.41 & 0.800 & 0.18 & 9.54 \\
\hline G5 & 50 & 40 & - & 10 & 0.09 & 10 & 5 & 1.60 & 0.26 & 4.41 & 0.800 & 0.18 & 9.54 \\
\hline
\end{tabular}

Table 3 Composition of the geopolymer mixes

3. táblázat A geopolimer keverékek összetétele 
was ranging from 400 to $4000 \mathrm{~cm}^{-1}$ [32]. Thermogravimetry conducted using DT-50 Thermal Analyzer (Schimadzu CoKyoto, Japan), where the samples were crushed, transferred immediately to an alumina crucible, held under isothermal conditions for $60 \mathrm{~min}$ at $40^{\circ} \mathrm{C}$ to equilibrate in a nitrogen environment $\left(\mathrm{N}_{2}\right.$ flowing at $\left.200 \mathrm{ml} / \mathrm{min}\right)$, and then heated to $1000{ }^{\circ} \mathrm{C}$ at $10^{\circ} \mathrm{C} / \mathrm{min}$ in the same gas environment.

\section{Results and discussion}

\subsection{Fourier transform infra-red (FTIR)}

FTIR spectra of 28 days (control) hybrid alkali activated composites incorporating $10 \mathrm{wt} . \%$ glass wastes or silica fume (Fig. 2) and having various ratios of multiwall carbon nanotube (MWCNT) from 0.01 up to 0.09 wt.\% indicates the growth of the asymmetric bands for amorphous geopolymer constituents for T-O-Si at about $1030 \mathrm{~cm}^{-1}$ in both mixes with increasing the MWCNT up to 0.07 wt.\%, while decreasing with further increase in nanotube. It can be also noticed in glass waste mixes shifting of the previous main asymmetric band into lower wave number $\left(980 \mathrm{~cm}^{-1}\right)$ as related to the increased amorphous geopolymer constituents than silica fume composites, where the increased fine structure $(38 \mu \mathrm{m})$ of glass waste in addition to high alkalis within; facilitate and enhance geopolymer formation.
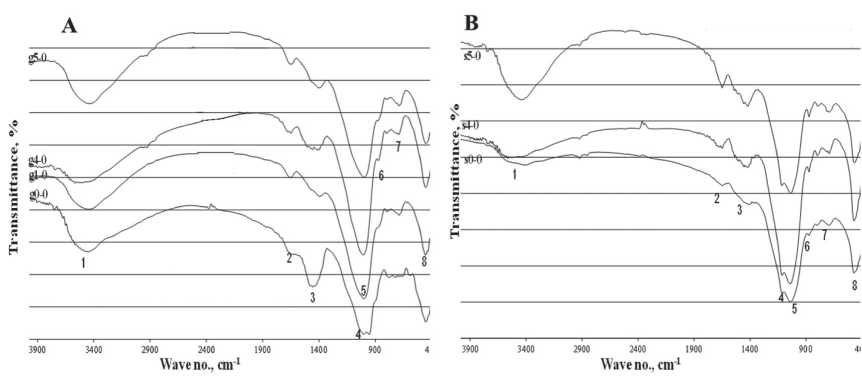

Fig. 2 FTIR spectra of 28 days alkali activated geopolymer specimens having various ratios of MWCNT, A) glass waste mixes; B) silica fume mixes. [1: Stretching vibration of $\mathrm{O}-\mathrm{H}$ bond, 2: Bending vibrations of $(\mathrm{HOH})$, 3: Stretching vibration of $\mathrm{CO}, 4$ : Asymmetric stretching vibration ( $\mathrm{Si}-\mathrm{O}-\mathrm{Si}$ ), 5: Asymmetric stretching vibration (T-O-Si), 6: Out of plane bending vibration of $\mathrm{CO}, 7$ : Symmetric stretching vibration (Si-O-Si), 8: Bending vibration (Si-O-Si and $\mathrm{O}-\mathrm{Si}-\mathrm{O})]$

2. ábra 28 napos alkáli aktivált geopolimer minták FTIR spektrumai, különbözö arányú MWCNT tartalommal, A) üveghulladékkal keverve; B) szilikaporral keverve.

Another main featured band in both patterns is asymmetric stretching vibration $(\mathrm{Si}-\mathrm{O}-\mathrm{Si}$ ) related to non-solubilized particles at about $1100 \mathrm{~cm}^{-1}$ which almost vanished with increasing MWCNT up to $0.07 \%$ reflecting the efficiency of nano-tube in enhancing anddissolving of unreacted constituents forming reactive amorphous geopolymer constituents. However, the intensity of previous band in silica fume mixes is higher than glass waste mixes reflecting the increased geopolymerization and activation of glass waste mixes than silica fume mixes. Increasing MWCNT ratios beyond $0.07 \%$ results in increasing $\mathrm{O}-\mathrm{H}$ bands at about 3430 , $1600 \mathrm{~cm}^{-1}$ which may be connected to the increased porosity with nano increase due to agglomeration of excess unreacted MWCNT, this note can be connected with the increased carbonate bands at about $1410 \mathrm{~cm}^{-1}$ as well as out of plane bending vibration band at $870 \mathrm{~cm}^{-1}$. Another important note from both pattern is the increased $\mathrm{O}-\mathrm{H}$ bands in glass waste mixes as compared with silica fume mixes where the lower grain size of glass waste acquire much water than silica fume as tabulated in Table 3, also reflects the increased of CSH in previous one as a results of its increased reactivity as compared with silica fume $[32,14]$. Another small bands at about 795, 690, and $448-468 \mathrm{~cm}^{-1}$ for symmetric stretching vibration of (Si-O$\mathrm{Si})$ attributed to $\alpha$-quartz, symmetric stretching vibration ( $\mathrm{Si}-$ $\mathrm{O}-\mathrm{Si}$ ), bending vibration ( $\mathrm{Si}-\mathrm{O}-\mathrm{Si}$ and $\mathrm{O}-\mathrm{Si}-\mathrm{O}$ ) associated with quartz [33], respectively, which increased with MWCNT up to $0.07 \%$ then decrease, as related to the activation and enhancement done by nano materials and their efficiency in enhancing geopolymerization reaction.
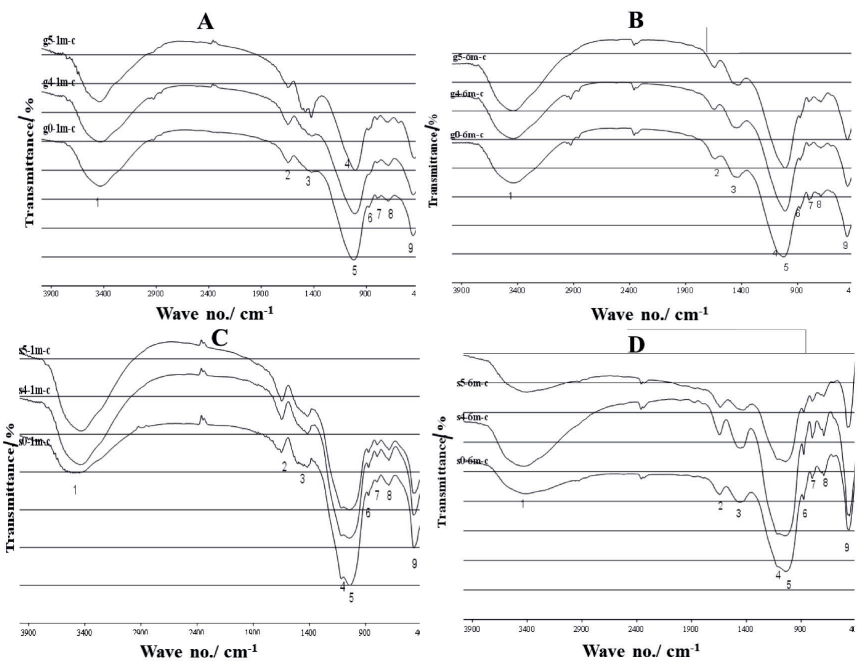

Fig. 3 FTIR spectra of alkali activated geopolymer specimens immersed in magnesium chloride solution and enhanced with various ratios of MWCNT: A) one month glass waste mixes, B) six month glass waste mixes, C) one month silica fume mixes, D) six month silica fume mixes. [1: Stretching vibration of $\mathrm{O}-\mathrm{H}$ bond, 2: Bending vibrations of $(\mathrm{HOH})$, 3: Stretching vibration of $\mathrm{CO}, 4$ : Asymmetric stretching vibration ( $\mathrm{Si}-\mathrm{O}-\mathrm{Si}$ ), 5: Asymmetric stretching vibration (T-O-Si), 6: Out of plane bending vibration of $\mathrm{CO}$ , 7: Symmetric stretching vibration ( $\mathrm{Si}-\mathrm{O}-\mathrm{Si}$ ) attributed to $\alpha$-quartz, \&: Symmetric stretching vibration (Si-O-Si), 9: Bending vibration ( $\mathrm{Si}-\mathrm{O}-\mathrm{Si}$ and $\mathrm{O}-\mathrm{Si}-\mathrm{O})]$

3. ábra Magnézium-klorid-oldatba meritett és az MWCNT különbözö aránnyal rendelkezö alkáli aktivált geopolimer minták FTIR-spektrumai: A) egy hónapos üveghulladék keverékek, B) hat hónapos üveghulladék-keverékek, C) egy hónapos szilikapor keverékek, D) hat hónapos szilikapor keverékek.

FTIR of glass waste geopolymer mixes incorporating various ratio of MWCNT immersed in 5\% magnesium chloride solution at one and 6 months, Fig. 3 (A,B); showed an increased broadness in asymmetric band at about $1000 \mathrm{~cm}^{-1}$ with MWCNT up to $0.07 \%$ (G4) which consistent with both amorphous C(A)-S-H structure formed by the activation of slag in alkaline media [34], and N-A-S-H gels formed in geopolymer binder systems derived from fly ash and metakaolin [35]. Further increase in nano-tube to $0.09 \%$ results in an increased intensity of asymmetric stretching vibration of ( $\mathrm{Si}-\mathrm{O}-\mathrm{Si})$ related to nonsolubilized particles at about $1100 \mathrm{~cm}^{-1}$ where the increased MWCNT agglomerates and inhibit the dissolution and polymerization of geopolymer precursors. It can be seen that intensity of the carbonate at about $1430 \mathrm{~cm}^{-1}(\nu \mathrm{C}-\mathrm{O})$ splitted into two peaks with MWCNT increase to $0.09 \%$ as related to the distorted nature of $\mathrm{CO}_{3}$ mineral and could be attributed to 
partial carbonation of C-S-H gel in air atmosphere [36]. One can notice a slight increase in carbonation bands at 870 and $1430 \mathrm{~cm}^{-1}$ with immersion time increase to 6 months, also the hydration bands at about $3430 \mathrm{~cm}^{-1}$ increased with MWCNT and with time increase where the dissolved constituents undergo hydration forming additional binding materials (CSH). The two patterns of glass waste mixes (Fig. 3(A,B)) showed little evidence of Friedel's salt formation where the last phase formed at about $3640 \mathrm{~cm}^{-1}, 3480 \mathrm{~cm}^{-1}(\mathrm{vOH}), 1621$ $\mathrm{cm}^{-1}\left(\delta \mathrm{H}_{2} \mathrm{O}\right), 785 \mathrm{~cm}^{-1}, 620 \mathrm{~cm}^{-1}$, and $532 \mathrm{~cm}-1$ (vibration of $\mathrm{M}-\mathrm{O}$ ir $\mathrm{M}-\mathrm{O}-\mathrm{H}$ bands) are characteristic of Friedel's salt [37], where all bands except one at $532 \mathrm{~cm}^{-1}$ were overlapped by other bands, so only this peak shows the formation of Friedel's salt after 3 months of immersion in chloride solution. However the increased content of MWCNT leads to agglomeration, so more sodium cations are available for carbonation as clearly will be seen in Fig. 6 .

On the other hand, silica fume based mixes immersed in chloride solution at 1 and 6 months (Fig. 3(C,D)) showed the same behavior with respect to the added MWCNT, whereas the main difference in those mixes are the presence of the shoulder at about $1100 \mathrm{~cm}^{-1}$ for non-solubilized silica which is inversely proportional with the asymmetric band of T-O-Si at about $1000 \mathrm{~cm}^{-1}$ where their increase reflect the deficiency in dissolving and polymerize the constituents of the geopolymer. Also, the hydration bands in silica fume decreases with time up to 6 months, as well as carbonate bands with time giving an indication about the continuous consumption of free alkalis and incorporation in geopolymer formation in spite the mix of $0.07 \%$ MWCNT acquired the highest content of hydration bands as reflected on the increased combined water content in the geopolymer network as well as the formed CSH and CASH phases. Another difference is the absence of the shoulder at about $1100 \mathrm{~cm}^{-1}$ for non- solubilized silica in glass waste mixes where high reactivity if glass waste enhance their dissolution and incorporation in geopolymerization reaction, however in silica fume there are still some unreacting constituents which not incorporated in the reaction.

FTIR spectra of geopolymer mixes incorporated glass waste and silica fume immersed in 5\% magnesium chloride solution up to 6 months, and enhanced by 0.07\% MWCNT (Fig. 4 $(\mathrm{A}, \mathrm{B}))$. The pattern of both mixes exhibit an increased intensity in the amorphous geopolymer constituents as represented by asymmetric stretching vibration of T-O-Si at about $1000 \mathrm{~cm}^{-1}$ with slight shifting to lower wave number with time. Also, there is an increased dissolution of unreacted slag materials with curing time up to 6 months as illustrated from the decreased asymmetric band at about $1100 \mathrm{~cm}^{-1}$ for non-solubilized particles as well as symmetric vibration of $\alpha$-quartz at about $797 \mathrm{~cm}^{-1}$, confirming the activation and nucleating efficiency increase by MWCNT [38]. The band at $690 \mathrm{~cm}^{-1}$ is attributed to the symmetric vibration mode of the $\mathrm{Si}-\mathrm{O}-\mathrm{Si}$ or $\mathrm{Al}-\mathrm{O}-\mathrm{Si}$ bonds. This band corresponds to $\mathrm{C}-\mathrm{A}-\mathrm{S}-\mathrm{H}$ type phases, and the zeolites forming in these systems, as identified by XRD (Figs. 5, 6). This band has also been observed in unreacted slag [39], and has been attributed to gehlenite. All infrared band assignments follow references [40-42].
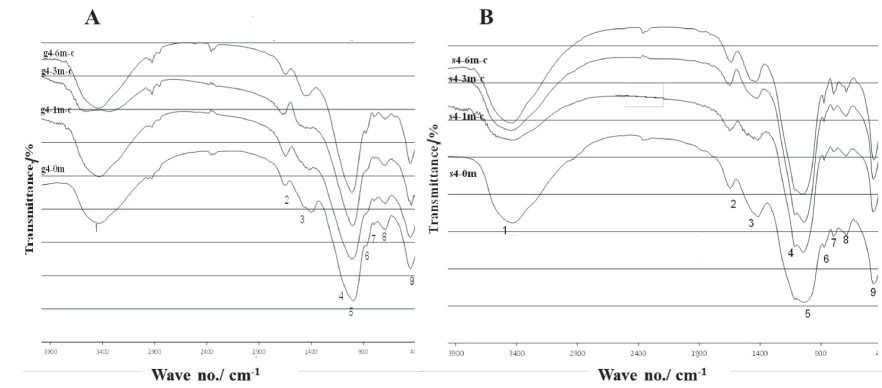

Fig. 4 FTIR spectra of alkali activated Geopolymer specimens enhanced with $0.07 \%$ MWCNT immersed in magnesium chloride solution up to six months, A) glass waste mixes; $\mathrm{B}$ ) silica fume mixes. [1: Stretching vibration of $\mathrm{O}-\mathrm{H}$ bond, 2: Bending vibrations of $(\mathrm{HOH}), 3$ : Stretching vibration of $\mathrm{CO}, 4$ : Asymmetric stretching vibration (Si-O-Si), 5: Asymmetric stretching vibration (T-O-Si), 6: Out of plane bending vibration of $\mathrm{CO}, 7$ : Symmetric stretching vibration ( $\mathrm{Si}-\mathrm{O}-\mathrm{Si}$ ) attributed to $\alpha$-quartz, 8: Symmetric stretching vibration (Si-O$\mathrm{Si}$ ), 9: Bending vibration ( $\mathrm{Si-O}-\mathrm{Si}$ and $\mathrm{O}-\mathrm{Si}-\mathrm{O}$ )]

4. ábra Legfeljebb hat hónapig magnézium-klorid-oldatba merített 0,07\% MWCNT tartalmú alkáli aktivált geopolimer minták FTIR-spektrumai A) üveghulladék keverékek; B) szilikapor keverékek.

There is a decrease in the carbonation bands observed with MWCNT and time, where the carbonate constituents in slag materials lead to the growth of the carbonate band as discussed above, showing that the carbonates identified in this raw material do not react significantly under alkaline activation conditions [43]. The $\mathrm{CO}_{3}{ }^{2-}$ vibration band decreases with time as attributed to the fact that the increased nucleation of MWCNT increase the formation of geopolymer structure and decrease the availability of free $\mathrm{Na}^{+}$species which will be subjected to carbonation.

\subsection{X-ray diffraction (XRD)}

XRD patterns of six months alkali-activated geopolymer mixes based on glass waste and silica fume incorporating various ratio of MWCNT (0, 0.07, 0.09 wt.\%), immersed in magnesium chloride solution are shown in Fig. $5(\mathrm{~A}, \mathrm{~B})$. The pattern of glass waste mixes (Fig. 5A) illustrate mostly absence of hump in the region of $17^{\circ}$ to $35^{\circ} 2 \theta$ which characterize glassy phases, this region considered as vital key in geopolymer characterization, where any increase in this hump will be reflected on the performance and efficiency of the resulting geopolymer gel. Also, there is sharp peak for Friedel's salt at

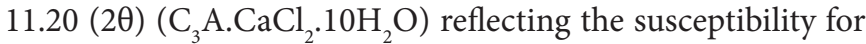
this mix for chloride attack.

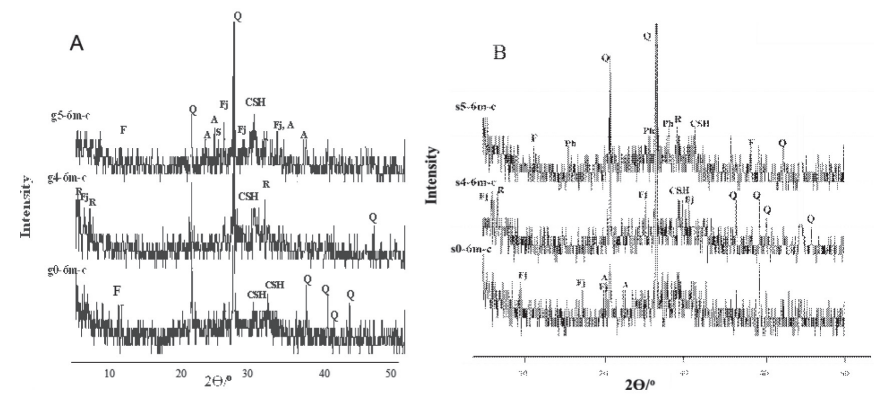

Fig. 5 XRD pattern of six months immersed alkali activated geopolymer specimens in magnesium chloride solution; A) glass waste mixes, B) silica fume mixes [Q:Quartz, A:ZeoliteA, Fj: Faujasite, F: Friedel's salt, R: Reversedite, CSH: Calcium silicate hydrate]

5. ábra Hat hónapig magnézium-klorid-oldatba merített alkáli aktivált geopolimer minták XRD ábrái; A) üveghulladék keverékek; B) szilikapor keverékek. 
It can be seen an increased broadness of this hump up on increasing MWCNT to $0.07 \%$ with the increase of CSH as well as reversedite phases $\left(\mathrm{C}_{3} \mathrm{~S}_{2} \mathrm{H}_{3}\right)$ which is one of the calcium hydrate phases that add additional strengthening as well as nucleating sites for geopolymer formation and accumulation [44], the increased intensity of this hump favors the activation done by MWCNT resulting in enhancement of geopolymer reaction. Further increase in nano results in an agglomeration, forming weak points within the matrix which hinder geopolymer propagation leading to formation of short zeolite chains as confirmed by the increased intensity of zeolite phases (faujasite, zeolite A, sodalite) on the expense of the amorphous geopolymer structure. This decrease in the amorphous geopolymer phases made the matrix more prone to chloride attack as indicated by the appearance of Friedel's salt, but its intensity still much lower than control mix which suggests the ability of MWCNT even in high dose to suppress the chloride attack.

The behavior of silica fume based mixes almost similar to those of glass waste mixes (Fig. $5 B$ ), except the decreased hump in the region from $17-35^{\circ}(2 \theta)$ related to the amorphous content as well as the hump in the region $6-10^{\circ}(2 \theta)$ for aluminosilicate gel where the increased reactivity of glass waste than silica fume favors the increased hump broadness in glass waste mixes than that of silica fume. The main remark in silica fume mixes also is the increased zeolite content as related to its lower reactivity which favor the zeolite formation than amorphous geopolymer constituents especially up on using high MWCNT dose while accompanied by the increased intensity of Friedel's salt.
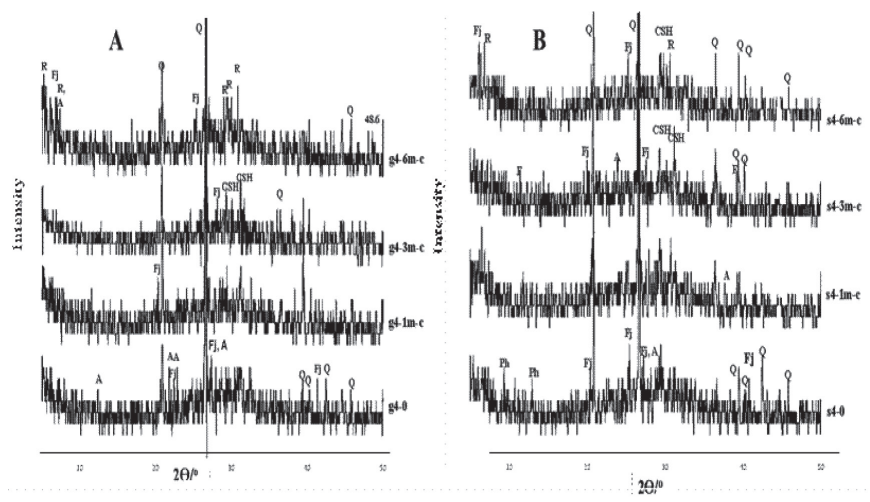

Fig. 6 XRD pattern of alkali activated Geopolymer specimens enhanced with $0.07 \%$ MWCNT immersed in 5\% magnesium chloride solution up to 180 days. A) glass waste mixes, B) silica fume mixes. [Q:Quartz, A:ZeoliteA, Fj: Faujasite, R: Reversedite, CSH: Calcium silicate hydrate, $P h$ : Phylipsite]

6. ábra Legfeljebb hat hónapig 5\%-os magnézium-klorid-oldatba merített 0,07\% MWCNT tartalmú alkáli aktivált geopolimer minták XRD ábrái A) üveghulladék keverékek; B) szilikapor keverékek.

On examining the effect of immersion time up to 6 months on the optimum mixes incorporating $0.07 \%$ MWCNT in glass waste and silica fume mixes as illustrated in Fig. 6, there is continuous growth in amorphous geopolymer hump with time in addition to the increased $\mathrm{CSH}$-phases as attributed to the effect of the $\mathrm{NaOH}$ alkaline solution during processing as discussed in a previous investigation [45]. The carboxylate based superplasticizer was effective in dispersing MWCNTs at 0.07 wt.\% and lower, where most of MWCNT interact and activate the geopolymerization reaction forming three dimensional networks. Another main concluded remark was the increased faujasite phase in silica fumes mixes up to 3 months whereas in glass waste mixes there is continuous growth and crystallization of CSH. The increased zeolite phases in silica fume mixes made the matrix more prone to chloride attack especially at 3 months as represented by peaks due to Friedel's salt, while beyond this age the progress of geopolymer formation results in increasing the medium alkalinity which will destabilize the formed Friedel's salt leading to lowering in its intensity $[46,47]$.

It is likely that a significant proportion of $\mathrm{Na}^{+}$species is consumed in the activation of binding constituents to form a sodium aluminosilicate-type gel, reducing the availability of $\mathrm{Na}^{+}$species in the pore solution [48] and, therefore, reducing the alkalinity from the high levels which would favor zeolite growth, even with the higher alkali dosage added to these samples. It can be noticed also the absence of calcite phases mostly in all mixes as well as with immersion time which reveals the absence of free alkalis as they are mostly consumed in geopolymer formation. This observation come in accordance with FTIR pattern where the intensity of carbonate bands are very small while in XRD there are no carbonates as the XRD tool concerned about crystalline content of the minerals which can detect only more than $3 \%$, which means that calcite phases are too small in the matrix.

\subsection{Differential thermo-gravimetric analysis (DTG)}

Differential thermogravimetric curves for geopolymer composites incorporating various ratio of MWCNT are represented in Figs. 7-10. The pattern of one month glass waste and silica fume geopolymer composites having $0,0.07$ and $0.09 \%$ MWCNT represented in differential thermograms (Figs. $7,8)$, showed a characteristic two endotherms at temperature lower than $68{ }^{\circ} \mathrm{C}$ as well as endothermic band lower than 149 ${ }^{\circ} \mathrm{C}$; the first associated with the loss of freely evaporable water present in large pores of the aluminosilicate type product (geopolymer gel) for Mk-geopolymer [26,49], while the second associated with the dehydration of a C-S-H gel [50], as this is the main reaction product identified in GBFS-rich blended binders [40,51]. In addition to another endothermic peak at temperatures at about $590,615,725{ }^{\circ} \mathrm{C}$, this attributed to the presence of calcium carbonates of varying crystallinity as has been observed in previous studies of alkali-activated slag using a similar precursor [50] as a consequence of weathering of the slag before sample preparation. Another endothermic peak can be distinguished in some mixes in the range $309-331^{\circ} \mathrm{C}$ attributed to dehydroxylation by condensation of the bound silanol groups in zeolite of Faujasite, which is completed at $500{ }^{\circ} \mathrm{C}$ [51].

Fig. 7 illustrate the growth in the intensity of endothermic peak at about $62{ }^{\circ} \mathrm{C}$ with MWCNT increase to $0.07 \%$, with sharp increase in the endothermic peak for $\mathrm{CSH}$ at about $149{ }^{\circ} \mathrm{C}$ which reflect the increased efficiency of MWCNT in activating and enhancing geopolymer formation as well as $\mathrm{CSH}$, as coincide with XRD and FTIR observations. However, increasing MWCNT to $0.09 \%$ lead to a decreased intensity of endothermic peak at $62{ }^{\circ} \mathrm{C}$ as well as growth of endothermic peak at about $310{ }^{\circ} \mathrm{C}$ for zeolite dehydroxylation. Another main notice in this figure is the absence of endothermic peak for Friedel's salt at all MWCNT's ratios at $360-370{ }^{\circ} \mathrm{C}[52,53]$. 


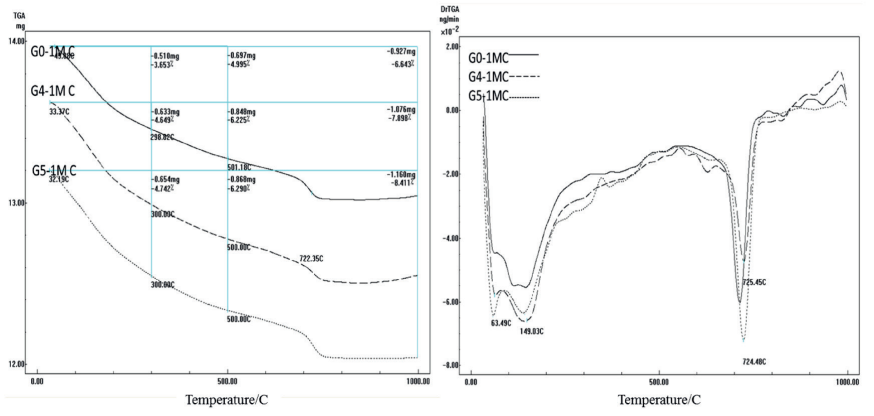

Fig. 7 Differential thermo-gravimetric pattern of one month alkali activated glass waste geopolymer specimens enhanced with various ratios of MWCNT and immersed in 5\% magnesium chloride solution.

7. ábra Egyhónapos 5\% -os magnézium-klorid-oldatba merített alkáli aktivált üveghulladék geopolimer minták termo-gravimetrikus mérési eredményei, különbözö MWCNT arányok esetén,

With respect to the carbonate which mentioned in previous studies of alkali-activated slag using a similar precursor [50] as a consequence of slag weathering before sample preparation. Considering that samples were cured and stored under controlled sealed conditions, a significant extent of carbonation is not expected to occur in the specimens assessed. The figure showed the lowest intensity of carbonation endotherm at $0.07 \%$ as confirmed by the dense structure of this matrix. None of the samples show significant weight loss above $725^{\circ} \mathrm{C}$.

Total weight loss for one month immersed glass waste geopolymer mixes in magnesium chloride solution varied with MWCNT giving $\sim 6.643, \sim 7.898$ and $\sim 8.411 \%$ for $0,0.07$ and $0.09 \%$, respectively. The total weight loss reflected the increased the amorphous aluminosilicate content with nano materials up to $0.07 \%$, while the increase in total weight loss with further nano increase related mainly to the increased zeolite formed (as seen from the endothermic at about $310^{\circ} \mathrm{C}$ for dehydroxylation of zeolite as mentioned before) as a result of agglomeration of excess nanotube leading to the decrease in the amorphous geopolymer constituents and forming short crystalline zeolite chains.
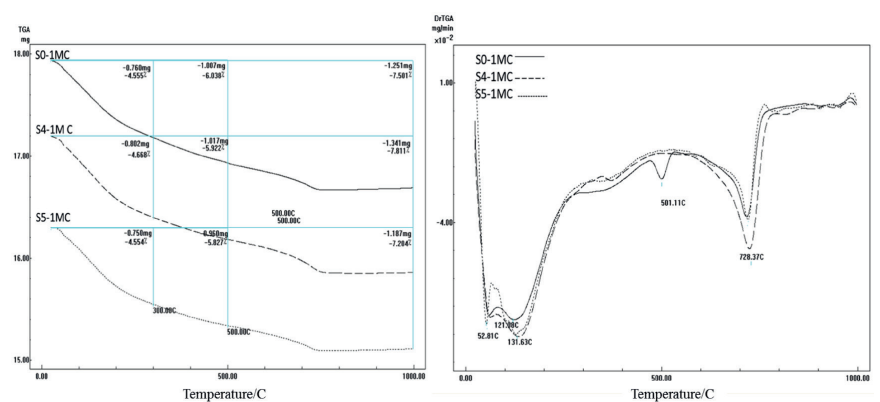

Fig. 8 Differential thermo-gravimetric pattern of one month alkali activated silica fume based geopolymer specimens enhanced with various ratios of MWCNT and immersed in 5\% magnesium chloride solution.

8. ábra Egyhónapos 5\% -os magnézium-klorid-oldatba merített alkáli aktivált szilikapor alapú geopolimer minták termo-gravimetrikus mérési eredményei, különbözö MWCNT arányok esetén,

In case of silica fume geopolymer mixes (Fig. 8), the same behavior with respect to MWCNT addition except that the endothermic peak for freely evaporable water in geopolymer shifted to lower temperature $\left(52{ }^{\circ} \mathrm{C}\right)$ indicating the lower matrix density of those mixes as compared with glass waste mixes and the free water of geopolymer is not tightly bound as the previous mixes. Also, the CSH shifted to lower temperature to $131{ }^{\circ} \mathrm{C}$ as the formed $\mathrm{CSH}$ binding materials are not of dense structure as compared with previous mixes, whereas the carbonate peaks are almost equal in intensity.

Total weight loss for one month immersed silica fume geopolymer mixes in magnesium chloride solution varied with MWCNT giving 7.501, 7.811 and $\sim 7.204 \%$ for $0,0.07$ and $0.09 \%$, respectively. The total weight loss reflected the increased the amorphous aluminosilicate content with nano materials up to $0.07 \%$, while its decrease as compared with glass waste related to the absence of zeolite peak at about $310{ }^{\circ} \mathrm{C}$ in silica fume mixes. On the other hand, prolonged immersion of glass waste geopolymer and silica fume mixes incorporating $0.07 \%$ MWCNT in magnesium chloride solution up to six months (Fig. 9, 10), there is a continuous increase in the amorphous aluminosilicate content at about $60{ }^{\circ} \mathrm{C}$, with the almost vanishing of zeolite dehydroxylation peak at $310^{\circ} \mathrm{C}$ as a resulted of continuous geopolymerization reaction, however at 6 months of immersion there is a new formed peak for zeolite dehydroxylation at about $87^{\circ} \mathrm{C}$. Also, a noticeable increase in the peaks related to $\mathrm{CSH}$ at about $149^{\circ} \mathrm{C}$ with the shifting to lower temperature of $133{ }^{\circ} \mathrm{C}$ as resulted from the difference in the nature of water bonded to the structure than in geopolymer gel, such as C-S-H gel [49], these observations come in accordance with XRD and FTIR illustrations as mentioned before.

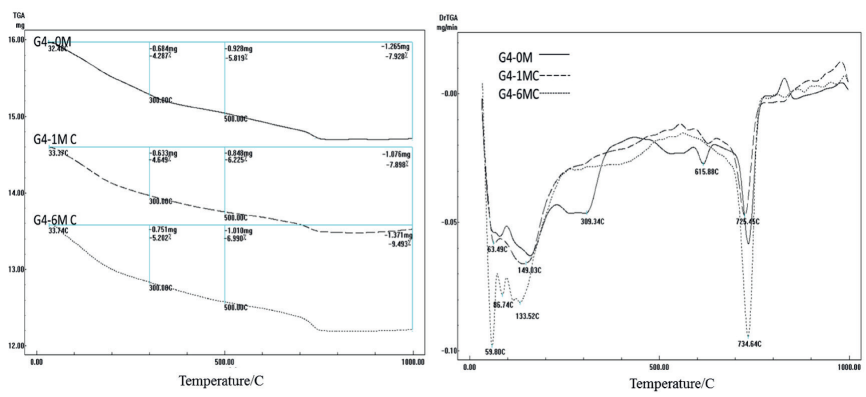

Fig. 9 Differential thermo-gravimetric pattern of alkali activated glass waste geopolymer specimens enhanced with $0.07 \%$ MWCNT and immersed in 5\% magnesium chloride solution up to six months

9. ábra Legfeljebb hat hónapig 5\% -os magnézium-klorid-oldatba merített, 0,07\% MWCNT tartalmú alkáli aktivált üveghulladék geopolimer minták termogravimetrikus mérési eredményei

On investigating the figure of silica fume mix, nearly there was symmetry with glass waste mix up on immersion in chloride solution except the absence of peak due to zeolite at about $87^{\circ} \mathrm{C}$ in addition to the increased broadness of the carbonate peaks at various temperatures from 590 to $730{ }^{\circ} \mathrm{C}$ as attributed to the presence of calcium carbonates of varying crystallinity, whilst in glass waste, the calcite peaks are narrow at $725^{\circ} \mathrm{C}$. Total weight loss for glass waste as well as silica fume geopolymer mixes incorporating $0.07 \%$ MWCNT immersed in magnesium chloride solution up to 6 months increased with time giving $\sim 7.93, \sim 7.90$ and $\sim 9.49 \%$ for 0,1 and 6 months, as well as $\sim 6.90, \sim 7.81, \sim 10.43 \%$, at 0,1 and 6 months, for glass waste and silica fume mix, respectively. This increase in the total loss attributed to the growth in the amorphous aluminosilicate content as well as $\mathrm{CSH}$ with time even under immersion in aggressive chloride solution. 


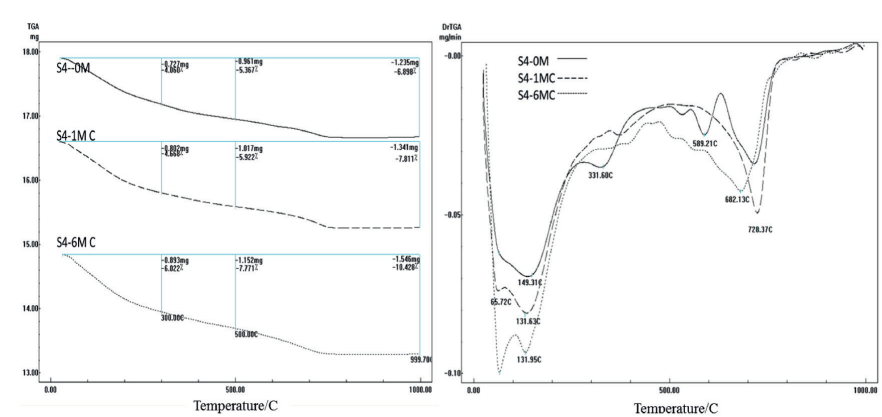

Fig. 10 Differential thermo-gravimetric pattern of alkali activated silica fume geopolymer specimens enhanced with $0.07 \%$ MWCNT and immersed in 5\% magnesium chloride solution up to six months

10. ábra Legfeljebb hat hónapig 5\%-os magnézium-klorid-oldatba merített, 0,07\% MWCNT tartalmú alkáli aktivált szilikaport alapú geopolimer minták termo-gravimetrikus mérési eredményei

\subsection{Compressive strength}

Fig. 11 shows the compressive strength of glass waste as well as silica fume geopolymer composites enhanced with various ratios of MWCNT; immersed in 5\% magnesium chloride solution up to 6 months. The results showed the increase of strength in all composites in spite of their immersion in the aggressive magnesium chloride solution, and reaching the maximum at $0.07 \%$ MWCNT while decreases with further increase in the carbon nanotube.
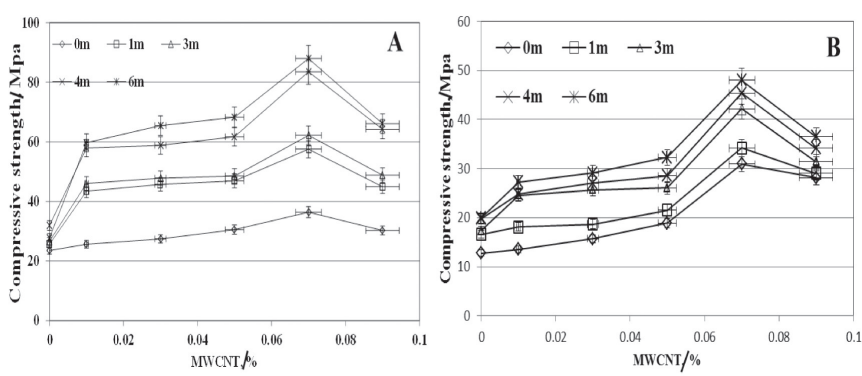

Fig. 11 Compressive strength of alkali activated geopolymer specimens enhanced with various ratios of MWCNT and immersed in magnesium chloride solution up to 6 months, A) glass waste mixes, B) silica fume mixes

11. ábra Alkáli aktivált geopolimer minták nyomószilárdsága, különböző MWCNT arányok esetén és magnézium-klorid-oldatba merítve 6 hónapig; A) üveghulladék keverékek; B) szilikapor keverékek.

As known the main deleterious effect up on immersion in magnesium chloride solution is the formation of Friedel's salt $\left(\mathrm{C}_{3} \mathrm{~A} \cdot \mathrm{CaCl}_{2} \cdot 10 \mathrm{H}_{2} \mathrm{O}\right)$ which known by its softening characteristics as well as their formed by-product magnesium hydroxide which known by its lower pozzolanic activity as well as its essential effect in lowering the $\mathrm{pH}$ of the medium which is the main driving force for the geopolymer reaction as well as its lower solubility which in turn results in hindering the propagation of hydration reaction as seen from the following equations:

$3 \mathrm{Ca}(\mathrm{OH})_{2}+\mathrm{Al}(\mathrm{OH})_{4}^{-} \rightarrow \mathrm{C}_{3} \mathrm{~A}+3 \mathrm{H}_{2} \mathrm{O}$

$\mathrm{Ca}(\mathrm{OH})_{2}+\mathrm{MgCl}_{2} \rightarrow \mathrm{CaCl}_{2}+\mathrm{Mg}(\mathrm{OH})_{2}$ (low solubility)

$\mathrm{CaCl}_{2}+\mathrm{C}_{3} \mathrm{~A}+10 \mathrm{H}_{2} \mathrm{O} \rightarrow \mathrm{C}_{3} \mathrm{~A} \cdot \mathrm{CaCl}_{2} \cdot 10 \mathrm{H}_{2} \mathrm{O}$ (Friedel's salt)

Magnesium ions with its lower solubility decrease medium $\mathrm{pH}$ forming $\mathrm{M}-\mathrm{S}-\mathrm{H}$ instead of C-S-H; which is known by its non-cementitious properties and leads to softening on prolong exposure time leading to destabilization of the hydration materials $[53,54]$.
In our case, optimization of the strength values for geopolymer composites containing $0.07 \%$ MWCNT ascribed to its spreading throughout the geopolymer matrix with a uniform density. Where, The good dispersion of MWCNTs was also attributed to the effect of the $\mathrm{NaOH}$ alkaline solution during processing as discussed in an earlier publication [45] and hydrophilic groups $(-\mathrm{COOH})$ in carboxylate based superplasticizer forming covalence-modified CNTs to improve interfacial interactions within composites, in which the - $\mathrm{COOH}$ groups form strong coordinate bonds with $\mathrm{Ca}^{2+}$ ions in geopolymer matrix, thus enhancing the formation of three dimensional geopolymer in addition to $\mathrm{CSH}[39,55]$. However, The carboxylate based superplasticizer was ineffective in dispersing MWCNTs in ratios more than $0.07 \%$, where most of MWCNT were agglomerated in the alumino-silicate gel and hinder the propagation of the three dimensional network.

Incorporated MWCNTs increase the geopolymerization rate after addition to the same system; therefore, the MWCNTs inhibit the retardation effect caused by aggressive chloride solution as reflected on the decreased intensity of the formed zeolite as well as Faujasite phases at the optimum MWCNT dose as seen from XRD, DTG and FTIR patterns. The activation effect done by MWCNT and their efficiency in resisting aggressive media can be explained by their ability to work as nucleation-sites in the system, where the functionalized MWCNTs provide different reaction sites for the crystal growth of geopolymer products [56].

The negative effect of MWCNT overdose than $0.07 \%$ was confirmed by the increased zeolite as well as Faujasite with the increased MWCNT, as the geopolymer network was terminated forming the crystalline zeolitic structures with lower reactive characteristics which facilitate the ingress of aggressive chloride solution as confirmed by slight peak at $0.09 \%$ in XRD pattern (Fig. 5) for Friedel's salt. Also, the intensity of the formed Friedel's salt in glass waste mixes is lower than that of silica fume mixes due to variation in reactivity of both as can be seen from their compressive strength values, where strength values for optimum MWCNT (0.07\%) after six months of immersion reaches about $88 \mathrm{MPa}$ while for silica fume mix at the same ratio reaches about $48 \mathrm{MPa}$. Zeolite formation is also well known to take place in $\mathrm{KOH}$-activated geopolymer, similar to their $\mathrm{NaOH}$-containing counterparts. However, crystallization is less rapid in $\mathrm{KOH} /$ metakaolin geopolymer compared to the $\mathrm{NaOH}$ / metakaolin system $[57,58]$ which confirmed the lower intensity in DTG for zeolite phases and lower intensity detected in XRD.

\section{Conclusions}

1. Hybridization of various aluminosilicate precursors including either glass wastes or silica fume produce sustainable building materials with superior resistivity to aggressive magnesium chloride solution.

2. Addition of various ratios of MWCNT to alkali activated hybrid composite increases and offers an extra nucleation sites for alkaline composite formation and accumulation.

3. MWCNT possess an extra enhancement in the stability of the produced alkali activated composites reaching to the optimum at $0.07 \%$. 
4. XRD, FTIR and DTG emphasized the absence of chloride bearing compounds (Friedel's salt) even at later ages except weak peaks in the control as well as mixes incorporating $0.09 \%$ MWCNT.

5. Glass wastes incorporating mixes encounter better resistivity to the aggressive solution than silica fume incorporating mixes due to the variation in their reactivity. Where the optimum mix $(0.07 \%$ MWCNT) in glass waste group acquired compressive strength of about $88 \mathrm{MPa}$ after 6 months of immersion, while optimum silica fume mix at the same ratio acquired about $48 \mathrm{MPa}$.

\section{References}

[1] Duxson, P.; Fernandez-Jimenez, A.; Provis, J.L.; Lukey, G.C.; Palomo, A.; van Deventer, J.S.J., "Geopolymer technology: the current state of the art", J Mater Sci., 2007;42(9):2917-33.

[2] Duxson, P.; Provis, J.L.; Lukey, G.C.; van Deventer, J.S.J., " The role of inorganic polymer technology in the development of green concrete", Cem Concr Res., 2007;37(12):1590-7.

[3] Habert, G.; d'Espinose de Lacaillerie, J. B.; Roussel, N., "An environmental evaluation of geopolymer based concrete production: reviewing current research trends', J. Cleaner Prod., 2011; 19: 1229.

[4] Rashad, A.M.; "Alkali-activated metakaolin: a short guide for civil engineer - an overview",Constr.Build.Mater., 2013; 41:751-765.

[5] Autef, A.; Joussein, E.; Gasgnier, G.; Rossignol, S., "Role of the silica source on the geopolymerization rate", J.Non-Cryst. Solids, 2012; 358:2886-2893.

[6] Aly, Z.; Vance, E.R.; Perera, D.S., "Aqueous dissolution of sodium aluminosilicate geopolymers derived from metakaolin", J.Nucl. Mater.,2012; 424:164-170.

[7] Khalaj, G.; Nazari, A., "Modeling split tensile strength of high strength self-compacting concrete incorporating randomly oriented steel fibers and $\mathrm{SiO} 2$ nanoparticles", Compos.B:Eng., 2012; 43:1887-1892.

[8] Khalaj, G.; Hassani, S.E.S.; Khezrloo, A.; Haratifar, E.-A.-D., "Split tensile strength of OPC-based geopolymers: application of DOE method in evaluating the effect of production parameters and their optimum condition", Ceram.Int.., 2014; 40:10945-10952.

[9] Jin, F.; Park, S., "A review of the preparation and properties of carbon nanotubes- reinforced polymer composites", Carbon Lett., 2011; 12:57-69.

[10] Saafi, M.; Andrew, K.; Tang, P.L.; Ghon, D.M.; Taylor, S.; Rahman, M.; Yang, S. ; Zhou, X., "Multifunctional properties of carbon nanotube/fly ash geopolymeric nanocomposites", Constr.Build.Mater.,2013; 49:46-55

[11] Tyson, B.; Al-Rub, A.; Yazdanbakhsh, A.; Grasley, Z., "Carbon nanotubes and carbon nanofibers for enhancing the mechanical properties of nanocomposites cementitious materials",J.Mater.CivilEng., 2011; 23: 1028-1035.

[12] Maeva, I.S.; Yakovlev, G.I.; Pervushin, G.N.; Buŕyanov, A.F.; Korzhenko, A.; Machyulaitis, R., "Modification of Anhydrite Compositions with Multilayer Carbon Nanotubes. Stroitel'nye materialy", Construction Materials, 2010; 7: 25-27.

[13] Kholmberg, K.; Iensson, B.; Kronberg, B.; i dr. Poverkhnostno- aktivnye veshchestva i polimery v vodnykh rastvorakh "Surfacants and polymers in aqueous solutions”, M.: BINOM. Lab. znanii, 2007. 528 p. (in Russian).

[14] Khater, H.M.; Abd el Gawwad, H.A., "Characterization of alkali activated geopolymer mortar doped with MWCNT", Construction and building materials, 2015; 102 (2016) :329-337.

[15] Khater, H.M.; Abd el Gawwad, H.A., "Effect of firing temperatures on alkali activated Geopolymer mortar doped with MWCNT", Advances in nano research "Techno press", 2015; 3(4) :225-242,

[16] Farag, A.B.; Ramadan, A.M.; Osman, T.A.; Khater, H.M.; Yosri, K., "Physicomechanical Characteristic of Slag Geopolymer Mortar Enhanced with Multiwall Carbon Nano-tube", International Journal of Engineering Trends and Technology (IJETT), 2015; 21(1): 52-60.

[17] Morsy, M.S.; Alsayed, S.H.; Aqel, M., "Hybrid effect of carbon nanotube and nanoclay on physicomechanical properties of cement mortar", Constr. Build.Mater., 2011; 25:145-149.
[18] Lio, H.; Baomin, W.; Yu, H.; Jun, Q.; Zhiqiang, G., "The influence of carbon nanotubes/ silica fume on the mechanical properties of cement -based composites", Rom.J.Mater., 2015;45:29-34.

[19] Hunashyal, A.M.; Tippa, S.V.; Quadri, S.S.; Banapurmath, N.R., "Experimental investigation on effect of carbon nano tubes and carbon fibres on the behavior of plain cement mortar composite round bars under direct tension”, Int. Sch. Res. Not.Nanotechnol., 2011; 201:1-6.

[20] Barnes, P.; Bensted J., "Structure and Performance of Cements", Second edition, Spon Press Taylor \& Francis Group, 2008.

[21] Yubin Jun; Seyoon Yoon; Jae Eun Oh, "A Comparison Study for ChlorideBinding Capacity between Alkali-Activated Fly Ash and Slag in the Use of Seawater", journal Appl. Sci. 2017; 7:971.

[22] Khater, H.M., "Influence of electric arc furnace slag on characterisation of the produced geopolymer composites", építôanyag , Journal of Silicate Based and Composite Materials, Sept. 2015; 67(3), 82-88, https://doi.org/10.14382/epitoanyag-jsbcm.2015.13.

[23] Khater , H.M.; Abd el Gawwad, H.A., " Synthesis and characterization of MK/Slag geopolymer composites enhanced by various ratios of nano kaolin” , épitôanyag $\$$ Journal of Silicate Based and Composite Materials, August 2017; 69(2) :40-48, https://doi.org/10.14382/epitoanyag-jsbcm.2017.8.

[24] Han B; Yu X; Ou J., "Multifunctional and smart carbon nanotube reinforced cement-based materials", Nanotechnology in Civil Infrastructure, Springer, 2011; 1:47.

[25] Collins, F.;Lambert, F.; Duan,W.H., "The influence of admixtures on the dispersion, workability, and strength of carbon nanotube-OPC paste mixtures", Cem Concr Compos., 2012; 34(9):1067-74.

[26] Weitzel, B; Hansen, MR; Kowald, TL;Müller, T; Spiess, HW; Trettin, HFR, "Influence of Multiwalled Carbon Nanotubes on the Microstructure of CSH-Phases" , In proceeding of 13th congress on the Chemistry of Cement, 3-8 july 2011, Madrid, Spain.

[27] El-Sayed, H. A.; Abo El-Enein, S. A.; Khater, H. M.; Hasanein, S. A., "Resistance of alkali activated water cooled slag geopolymer to sulfate attack", Ceramics - Silikáty, 2011; 55: 153-160.

[28] ASTM C1152, "Standard Test Method for Acid-Soluble Chloride in Mortar and Concrete", Annual Book of ASTM Standards; ASTM International: West Conshohocken, PA, USA, 2008.

[29] Saikia, N.; Usami, A.; Kato, S.; Kojima, T. "Hydration behavior of ecocement in presence of metakaolin", Resource Progressing Journal, 2004; 51: 35-41.

[30] Taha, A. S.; El-Didamony, H.; Abo.EL-enein, S. A.; Amer, H. A. "Physicochemical properties of supersulphated cement pastes", ZementKalk-Gips, 1981; 34:351-353.

[31] ASTM C109M "Standard Test Method for Compressive Strength of Hydraulic Cement Mortars", Annual Book of ASTM Standards; ASTM International: West Conshohocken, PA, USA ,2016.

[32] Alexandre Silva de Vargas; Denise.C.C. Dal Molin; Ângela.B. Masuero; Antônio.C.F. Vilela; Joao Castro-Gomes; Ruby M. Gutierrez, "Strength development of alkali-activated fly ash produced with combined $\mathrm{NAOH}$ and $\mathrm{CA}(\mathrm{OH}) 2$ activators", cement and concrete composites, 2014; 53, 341-349.

[33] Bakharev, T., "Durability of geopolymer materials in sodium and magnesium sulfate solutions", Cement and Concrete Research, 2005; 35: 1233-1246.

[34] Puertas, F.; Palacios, M.; Manzano, H.; Dolado, J.S.; Rico, A.;Rodríguez, J., "A model for the C-A-S-H gel formed in alkali-activated slag cements". J Eur Ceram Soc., 2011; 31(12):2043-2056

[35] Garcia-Lodeiro, I.; Palomo, A.; Fernández-Jiménez, A.; Mac- Phee, D.E., "Compatibility studies between N-A-S-H and C-A-S-H gels. Study in the ternary diagram $\mathrm{Na}_{2} \mathrm{O}-\mathrm{CaO}-\mathrm{Al} 2 \mathrm{O} 3-\mathrm{SiO} 2-\mathrm{H}_{2} \mathrm{O}$ ", Cem Concr Res., 2011; 41(9):923-931.

[36] Rees, C.A.; Provis, J.L.; Lukey, G.C.; van Deventer, J.S.J., “Attenuated total reflectance Fourier transform infrared analysis of fly ash geopolymer gel aging", Langmuir, 2007; 23(15):8170-8179.

[37] Kalinkin, A. M.; Politov, A. A.; Boldyrev, V. V.; Kalinkina, E. V.; Makarov, V. N.; Kalinnikov, V. T., "Study of Mechanical activation of Diopside in a $\mathrm{CO}_{2}$ Atmosphere”, J. Mater. Syn. Proc., 2002; 38: 163-167.

[38] Dai,Y.; Qian,G.; Cao, Y.; Chi, Y.; Xu, Y.; Zhou, J., "Effective removal and fixation of $\mathrm{Cr}(\mathrm{VI})$ from aqueous solution with Friedel's salt", J. Hazard. Mater., 2009; 170: 1086-1092. 
[39] Jiang, X.; Kowald, T.; Staedler, T.; Trettin, R., "Carbon nanotubes as a new reinforcement material for modern cement-based binders”, RILEM Proceedings, 2nd International Symposium on Nanotechnology in Construction, 2005; 209-213.

[40] Bernal, S.A.; Provis, J.L.; Rose, V.; Mejía de Gutiérrez, R., “Evolution of binder structure in sodium silicate-activated lag metakaolin blends", Cem. Concr. Compos.,2011; 33(1):46-54.

[41] Huang, C. K.; Kerr, P. F., "Infrared study of the carbonate minerals". Am. Mineral., 1960; 45: 311.

[42] Farmer, V. C., “The Infrared Spectra of Minerals". London: Mineralogical Society, 1974.

[43] Bernal, S.A.; Rodríguez, E.D.; de Gutiérrez, R.M.; Provis, J. L.; Delvasto, S., "Activation of Metakaolin/Slag Blends Using Alkaline Solutions Based on Chemically Modified Silica Fume and Rice Husk Ash", Waste Biomass Valor,2012; 3:99-108.

[44] Rees, C. A. ; Provis, J. L.; Lukey, G. C., van Deventer, J. S. J., "The mechanism of geopolymer gel formation investigated through seeded nucleation", Colloids Surf. A, 2008; 318: 97-105.

[45] Heister, E.; Lamprecht, C.; Neves, V.; Tîlmaciu, C.; Datas, L.; Emmanuel Flahaut, E., "Higher dispersion efficacy of functionalized carbon nanotubes in chemical and biological environments". ACS Nano, 2010; 4(5):2615-26

[46] Brown, P.W.; Bothe, J.V.,"The stability of ettringite”, Adv. Cem. Res.;1993; 5: 47-63.

[47] Famy, C., "Expansion of heat-cured mortars", PhD Thesis, Univ. of London, 1999; 256p.

[48] Duxson, P.; Provis, J. L.; Lukey, G. C.; van Deventer, J. S. J. ; Separovic, F.; Gan, Z. H., “39K NMR of Free Potassium in Geopolymers," Ind. Eng. Chem. Res., 2006; 45 (26): 9208-10.

[49] Alarcon-Ruiz, L.; Platret, G.; Massieu, E.; Ehrlacher, A, "The use of thermal analysis in assessing the effect of temperature on a cement paste", Cem. Concr. Res.,2005; 35(3): 609-613.

[50] Buchwald, A.; Tatarin, R.; Stephan, D., "Reaction progress of alkalineactivated metakaolin-ground granulated blast furnace slag blends",J Mater Sci., 2009; 44:5609-5617.
[51] Engelhardt, G.; Felsche, J.; Sieger, P., “The Hydrosodalite System $\mathrm{Na} 6+x[\mathrm{SiAlO} 4] 6(\mathrm{OH}) \mathrm{x} . \mathrm{nH} 2 \mathrm{O}$ : Formation, Phase Composition, and Deand Rehydration Studied by 1H, 23Na, and 29Si MAS-NMR Spectroscopy InTandem with Thermal Analysis, X-ray Diffraction, and IR Spectroscopy," J. Am. Chem. Soc., 1992;114: 1173-82.

[52] Luo, R.; Cai, Y.; Wang, C.; Huang, X., "Study of chloride binding and diffusion in GGBS concrete", Cement and Concrete Research,2003; 33:1 $-7$

[53] Khater, H.M.,"Influence of Metakaolin on Resistivity of Cement Mortar to Magnesium Chloride Solution”, J. Mater. Civ. Eng., 2011; 23(9): 12951301.

[54] Bonen, D., "A micro structural study of the effect of produced by magnesium sulfate on plain and silica fume-bearing Portland cement mortars", Cement and Concrete Research, 1993; 23:541-553.

[55] Peyvandi, A; Soroushian, P.; Abdol, N, "Surface-modified graphite nanomaterials for improvedreinforcement efficiency in cementitious paste", Carbon, 2013; 63: 175-186.

[56] Temuujin, J.; van Riessen, A.; Williams, R., "Influence of calcium compounds on the mechanical properties of fly ash geopolymer pastes", J. Hazard. Mater., 2009; 167, (1-3), 82-88.

[57] Li, Y; Wang, P.; Zhao, X., "Mechanical behaviour and microstructure of cement composites incorporating surface-treated multi-walled carbon nanotubes", Carbon, 2006; 43: 1239-1245.

[58] Duxson, P.; Mallicoat, S. W.; Lukey, G. C.; Kriven, W. M.; Van Deventer, J. S. J., " mechanical properties of metakaolin-based geopolymers", Colloids and Surfaces A - Physicochemical and Engineering Aspects,2006; 292:820

$\underline{\text { Ref.: }}$

Khater, H. M.- El Nagar, Abdeen: Evaluation of chloride resistance of silica fume and glass waste MWCNT-geopolymer composite Építőanyag - Journal of Silicate Based and Composite Materials, Vol. 73, No. 2 (2021), 44-53.p. https://doi.org/10.14382/epitoanyag-jsbcm.2021.8

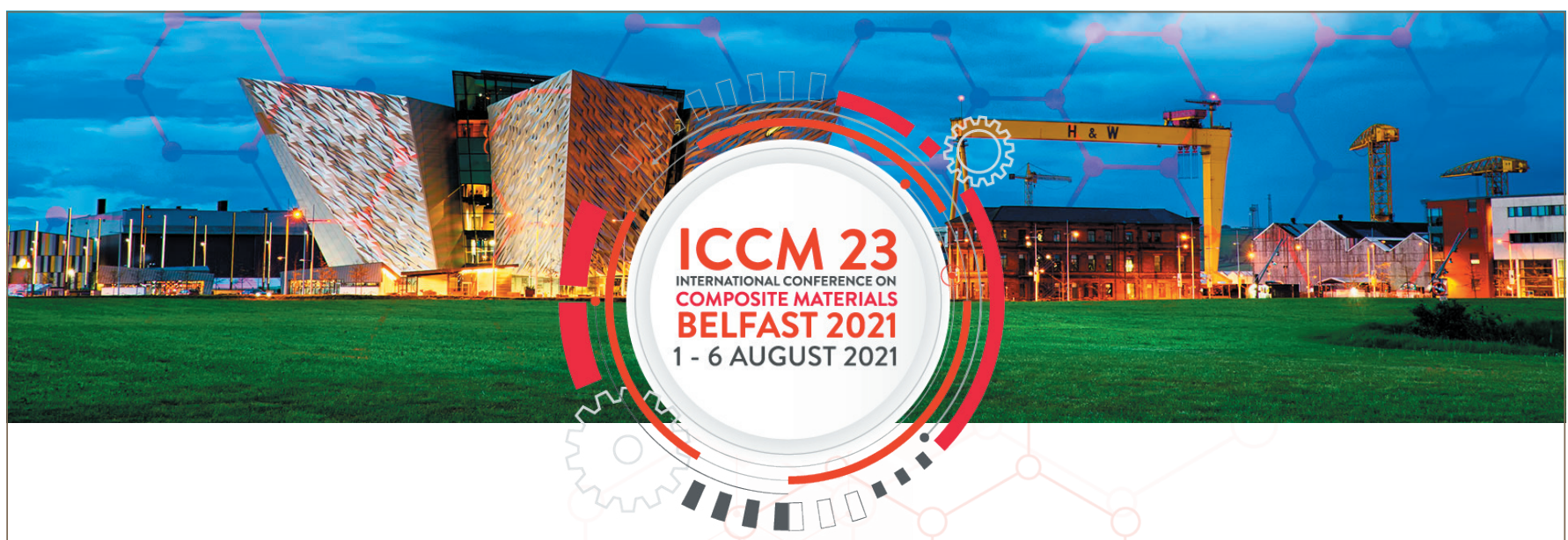

The 23rd International Conference on Composites Materials (ICCM 23) will be held in Belfast, Northern Ireland, from the 1st to 6th of August 2021. ICCM is the premier international conference in the field of composite materials and was first held in 1975 in the cities of Geneva and Boston. Since that time the conference has been held biennially in North American, European, Asian, Oceanic, and African cities.

ICCM 23 will attract the leading researchers and practitioners, to report and exchange ideas on the latest developments in the advancement and exploitation of a wide range of composites materials and structures. The general themes of material development, testing, modelling, manufacturing and design will encompass a breadth of topics which will provide a comprehensive global snap-shot of the state-of-the-art.

Plenary and keynote lectures from pre-eminent leaders in the field are planned, along with oral and poster presentations from an expected large delegation coming together in Belfast from all corners of the world. A number of site visits and an entertaining social programme are also planned.

\section{iccm23.org}

